\title{
Single particle analysis of ice crystal residuals observed in orographic wave clouds over Scandinavia during INTACC experiment
}

\author{
A. C. Targino ${ }^{1, *}$, R. Krejci ${ }^{1}$, K. J. Noone ${ }^{2}$, and P. Glantz ${ }^{1, * *}$ \\ ${ }^{1}$ Department of Meteorology, Stockholm University, 106 91, Stockholm, Sweden \\ ${ }^{2}$ IGBP Secretariat Royal Swedish Academy of Sciences, 104 05, Stockholm, Sweden \\ * now at: Department of Chemistry, University of York, YO10 5DD, York, UK \\ ** now at: Department of Applied Environmental Science, Stockholm University, 106 91, Stockholm, Sweden
}

Received: 5 July 2005 - Published in Atmos. Chem. Phys. Discuss.: 5 September 2005

Revised: 22 March 2006 - Accepted: 22 March 2006 - Published: 8 June 2006

\begin{abstract}
Individual ice crystal residual particles collected over Scandinavia during the INTACC (INTeraction of Aerosol and Cold Clouds) experiment in October 1999 were analyzed by Scanning Electron Microscopy (SEM) equipped with Energy-Dispersive X-ray Analysis (EDX). Samples were collected onboard the British Met Office Hercules C-130 aircraft using a Counterflow Virtual Impactor (CVI). This study is based on six samples collected in orographic clouds. The main aim of this study is to characterize cloud residual elemental composition in conditions affected by different airmasses. In total 609 particles larger than $0.1 \mu \mathrm{m}$ diameter were analyzed and their elemental composition and morphology were determined. Thereafter a hierarchical cluster analysis was performed on the signal detected with SEM-EDX in order to identify the major particle classes and their abundance. A cluster containing mineral dust, represented by aluminosilicates, Fe-rich and Si-rich particles, was the dominating class of particles, accounting for about $57.5 \%$ of the particles analyzed, followed by low-Z particles, $23.3 \%$ (presumably organic material) and sea salt (6.7\%). Sulfur was detected often across all groups, indicating ageing and in-cloud processing of particles. A detailed inspection of samples individually unveiled a relationship between ice crystal residual composition and airmass origin. Cloud residual samples from clean airmasses (that is, trajectories confined to the Atlantic and Arctic Oceans and/or with source altitude in the free troposphere) were dominated primarily by low-Z and sea salt particles, while continentally-influenced airmasses (with trajectories that originated or traveled over continental areas and with source altitude in the continental boundary layer) contained mainly mineral dust residuals.
\end{abstract}

Correspondence to: A. C. Targino

(act502@york.ac.uk)
Comparison of residual composition for similar cloud ambient temperatures around $-27^{\circ} \mathrm{C}$ revealed that supercooled clouds are more likely to persist in conditions where low$\mathrm{Z}$ particles represent significant part of the analyzed cloud residual particles. This indicates that organic material may be poor ice nuclei, in contrast to polluted cases when ice crystal formation was observed at the same environmental conditions and when the cloud residual composition was dominated by mineral dust. The presented results suggest that the chemical composition of cloud nuclei and airmass origin have a strong impact on the ice formation through heterogeneous nucleation in supercooled clouds.

\section{Introduction}

Aerosol-induced climate forcing is a combination of two effects, namely the direct and indirect effects, acting together to alter the amount of solar radiation that reaches the Earth's surface. The former effect arises from the scattering and absorption processes by aerosol particles, and the latter is a result of microphysical processes that modulate cloud properties, such as cloud albedo and cloud lifetime. While the direct effect has been studied extensively, the indirect effect still remains poorly understood and an accurate estimate of its impact on the climate has not been provided yet (IPCC, 2001).

The difficulty to estimate the indirect aerosol effect estimate lies partly on the complexity of the chemical and physical processes acting in clouds, since clouds are multiphase systems in which gaseous compounds, interstitial aerosol particles and liquid droplets coexist. The problem can become even more complicated when mixed phase clouds

Published by Copernicus GmbH on behalf of the European Geosciences Union. 
(mixture of ice particles and supercooled water droplets) are considered. These types of clouds are abundant in mid-latitude frontal systems and occur frequently also as orographic clouds. They are formed when the airflow is forced over a mountain or high ground and, as a consequence, stable gravity waves or trapped mountain lee waves can develop.

Most of the results reporting in situ measurements of ice crystal residuals have been obtained in cirrus clouds (e.g., Noone et al., 1993; Heintzenberg et al., 1996; Petzold et al., 1998; Seifert et al., 2003). The relatively longer lifetime of orographic clouds, as compared to e.g., cirrus or stratus clouds, as well as the specific airflow through the cloud, gives the possibility to use them as a natural flow reactor for studies of aerosol-cloud interactions. Orographic clouds reside longer over one point and do not move with the airmass, thus facilitating a detailed inspection of the unperturbed system in this semi-stationary regime. In many studies the characterization of aerosols and cloud droplets in the cloud multiphase systems has been approached by using bulk analysis technique (e.g., Georgii and Kleinjung, 1967; Grosch and Georgii, 1976; Hallberg et al., 1994), but little is known about the chemical composition of the aerosol particles activated into cloud elements. Since cloud properties are determined by aerosol-cloud interactions at the individual particle level, approaches that use bulk technique to describe these interactions will not be able to capture the details necessary to better understand the processes that actually determine cloud properties. Few studies, however, have been dedicated to the direct measurement and characterization of the chemical composition of ice elements in supercooled clouds.

Ice elements in clouds have several possible origins and generating mechanisms (Vali, 1985). There is a number of observational and modeling studies describing the most favorable conditions for the generation of cold clouds by homogeneous nucleation, that is, the spontaneous freezing of supercooled liquid droplets when water molecules become arranged into an ice embryo. Heymsfield and Miloshevich (1993) reported observations carried out in wave clouds and concluded that homogeneous nucleation dominates at temperatures below $-35^{\circ} \mathrm{C}$. Jensen et al. (1998) corroborated this hypothesis by modeling two of Heymsfield and Miloshevich's cases. They found that homogeneous freezing dominated at temperatures between -37 and $-62^{\circ} \mathrm{C}$.

In this study, we focus on heterogeneous ice nucleation processes, that is, the formation of ice crystals from a preexisting liquid cloud droplet, observed during the INTACC (INTeraction of Aerosol and Cold Clouds) experiment. Field et al. (2001) showed that during the INTACC a relatively warm regime (temperatures $>-35^{\circ} \mathrm{C}$ ) dominated the observation period, and as a consequence homogeneous freezing rates were strongly reduced and heterogeneous nucleation could have prevailed. Cooper and Vali (1981) made observations in mountain cap clouds at the temperature range from -15 to $-20^{\circ} \mathrm{C}$, concluding that heterogeneous nucleation was the main mechanism forming ice crystals. There are different pathways how ice crystal formation can occur. However, it is beyond the scope of this paper to describe the glaciation processes in the clouds. The main thrust of the present work is to characterize the chemical composition of individual residual particles found in ice crystals and to assess to what extent particles with different compositions can facilitate heterogeneous ice formation in the troposphere.

\section{The INTACC experiment}

\subsection{Sample collection}

Ice crystal residual particles were collected on board the British Met Office C-130 Hercules aircraft during the INTACC experiment, which took place in October 1999 over northern Scandinavia. The INTACC was implemented to yield a better understanding on how ice particles are formed in orographic clouds over the Scandinavian mountains and in thin-layered clouds associated with mid-latitude frontal systems. The flight operations were based at the Swedish Air Force Base (F4) in Östersund (63.17 $\left.\mathrm{N}, 14.29^{\circ} \mathrm{E}\right)$, Sweden. The aircraft was equipped with a number of instruments to investigate cloud microphysics, aerosol properties and gasphase chemistry. A general description of the instrumentation package used in the experiment is provided by Field et al. (2001).

During the INTACC a total of 15 mission flights were performed between 1 and 19 October 1999. The mission flights were typically $4 \mathrm{~h}$ in duration at altitudes between 4 and $8 \mathrm{~km}$, with a cruising speed of $150 \mathrm{~m} \mathrm{~s}^{-1}$. The wave clouds were sampled with straight level runs parallel to the wind at different heights with crosswind runs upwind and downwind of the cloud. Although flight patterns varied, each entailed a combination of ascending and descending profiles and constant altitude legs stretching over northern Sweden and Norway, enabling characterization of cloud elements in different airmasses. The aircraft location was determined from an onboard Global Positioning System (GPS).

This paper presents results of the Single Particle Analysis (SPA) of ice crystal residuals collected using a Counterflow Virtual Impactor (CVI). The operational principle of the CVI (Noone et al., 1988) is to direct a counterflow of dry particle free air in opposite direction to the motion of the aircraft. Small non-activated (interstitial) aerosol particles, which enter the CVI, initially with a relative velocity equal to the air speed, have insufficient inertia to penetrate the counterflow to a stagnation plane where the airflow velocity becomes zero. On the other hand, cloud droplets or ice crystals with radius larger than approximately $3.5 \mu \mathrm{m}$ have enough inertia to reach and penetrate through the stagnation plane. Cloud elements were evaporated inside the probe dry counterflow air leaving behind residual aerosol particles. Each crystal is assumed to leave only one residual particle behind, which has proven to be a valid assumption (Hallberg et al., 
1992; Glantz et al., 2003; Seifert et al., 2003). Measurements of the evaporated water from droplets and ice crystals using a dual-channel Lyman- $\alpha$ hygrometer (Noone et al., 1993) yielded information about the cloud water content (CWC). Cloud residuals for subsequent SPA were collected on $25 \mathrm{~mm}$ Nuclepore polycarbonate membrane filters with a pore diameter of $0.4 \mu \mathrm{m}$. The active sampling area was reduced to $7 \mathrm{~mm}$ in diameter using a Teflon mask supporting the filter from below. This reduction in the sampling area helps to enrich particle concentration on the sampling spot area and thus facilitates the analysis with the Scanning Electron Microscope (SEM). The filters were loaded in pairs into a custom-made filter holder and exposed predominantly during flight legs at constant altitude. Sampling times varied from 10 to $80 \mathrm{~min}$. Interstitial aerosol particles samples as well as aerosol samples upwind and downwind the orographic clouds were also collected and they will be discussed in a separate paper.

\subsection{Single particle analysis}

Prior to the analysis, the $7 \mathrm{~mm}$ diameter sampling spot was cut from the rest of the filter and mounted on a $2 \mathrm{~cm}$ diameter aluminum stub using conductive double-sided adhesive tape. A thin carbon coating was applied onto the sample surface to prevent the buildup of electric charge on the sample. The filter handling and preparations were carried out in clean chamber to avoid contamination.

SPA was performed using a Scanning Electron Microscope Philips XL 30 ESEM-FEG equipped with Energy Dispersive X-ray Analysis (EDX) at the Department of Geology and Geochemistry, Stockholm University. The X-ray detector consisted of a windowless $\mathrm{Si}(\mathrm{Li})$ detector with a spectral resolution of $157 \mathrm{eV}$ at $5.9 \mathrm{KeV}\left(\mathrm{Mn} \mathrm{K}_{\alpha}\right)$. The detector was calibrated with multielemental standards prior the analysis. The typical X-ray count rate during the analyses varied from 500-600 X-ray counts per second at an electron accelerating voltage between 20 and $25 \mathrm{kV}$. The X-ray spectrum was accumulated for $100 \mathrm{~s}$, excluding dead time of the detector. Because of the carbon (C) coating used and the presence of light elements like $\mathrm{C}$ and oxygen $(\mathrm{O})$ in the filter substrate, only elements with atomic number $\mathrm{Z} \geq 11$ (sodium, $\mathrm{Na}$ ) were considered in the analysis.

The selection of the particles for elemental analysis was performed manually using a secondary electron image. The filter area was divided into octants and the analysis started in the middle of the sampling spot and continued along each radius line towards the edge of sampling spot. For each recognized particle with size larger than $\sim 0.1 \mu \mathrm{m}$, its length and width were measured, regardless its size or shape. The mean Martin's diameter (Hinds, 1999), defined as the length of the horizontal line that appears to divide the particle into halves was used to size them, where "horizontal" refers to the apparent position of the particle in the field of view of the SEM.
Eight cloud samples were collected during 10 missions flown between 1 and 19 October 1999, of which six were used in this study. About 110 particles were analyzed per sample, except for one sample where only 75 particles were identified due to low aerosol loading. The number of particles analyzed in this study is relatively low, compared to other studies, where an automated procedure to recognize the particles was used (e.g., de Bock et al., 2000; Liu et al., 2000). However, as the deposition of the particles on the filters can be described as a stochastic process and the same analytical procedure has been employed for all filters, we assume that the results are not biased and that each sample analyzed is a good representation of the whole particle population on the filter. This assumption was tested by analyzing additional equal number of residual particles on two replicate filters. Results of this comparison are discussed later in this paper (see Sect. 3.2). A similar technique of particle selection has been used by Krejci et al. (2004).

One question that arises when performing SEM on ice crystals residuals is the susceptibility to contamination due to ice crystals etching the interior of the CVI probe and generating submicron stainless steel particles (Murphy et al., 2004). The dataset was thus treated in a way that allowed ruling out any corruption of the samples that might be produced from this kind of etching process. Initially, the SEM-EDX analysis was performed on fragments of the porous stainless steel used in the CVI to determine its composition. The most abundant elements in the CVI alloy are chromium (Cr), iron $(\mathrm{Fe})$ and nickel $(\mathrm{Ni})$, while silicon $(\mathrm{Si})$, sulphur $(\mathrm{S})$, molybdenum (Mo) and manganese (Mn) appear as faint signatures in the spectra. The ratios among the EDX peak counts of $\mathrm{Cr}$, $\mathrm{Fe}$ and $\mathrm{Ni}$ are very stable (Fe/Ni: from 5.5 to $8.7, \mathrm{Fe} / \mathrm{Cr}$ : from 3.26 to 3.82 and $\mathrm{Cr} / \mathrm{Ni}$ from 1.44 to 2.59 ). These elements have been chosen to represent typical signatures of stainless steel residues, since they have the smallest analysis and spectra fitting error (highest peak-to-background ratio). Any particle showing elemental composition within these ranges should be regarded as a result of the impactation process and extirpated from the dataset.

A simple methodology was used to screen the whole dataset (609 particles) in order to identify these particles. Particles resulting from abrasion of the CVI walls should contain at least $60 \%$ of $\mathrm{Fe}$, which is roughly the amount found in a 316 grade stainless steel. The first selection criterion was to retain only particles with $\mathrm{Fe}$ concentrations larger than $60 \%$. As a result, 58 particles $(9.5 \%$ of the initial dataset) could be classified as possible artifacts. Seifert et al. (2003) have discussed that particles containing trace amounts of $\mathrm{Si}, \mathrm{Na}, \mathrm{Ca}$, and $\mathrm{Al}$ in addition to $\mathrm{Fe}, \mathrm{Cr}$ and $\mathrm{Ni}$ are not a product of crystal impact, as it is unlikely that stainless steel particles would mix with any other material during the impactation. Following this criteria and a further requirement that $\mathrm{Cr}$ and $\mathrm{Ni}$ should also be present, the number of $\mathrm{Fe}-\mathrm{Cr}-\mathrm{Ni}$ containing particles dropped to 17 (2.8\% of the initial dataset). Out of these, 8 particles showed $\mathrm{Fe} / \mathrm{Ni}, \mathrm{Fe} / \mathrm{Cr}$ 

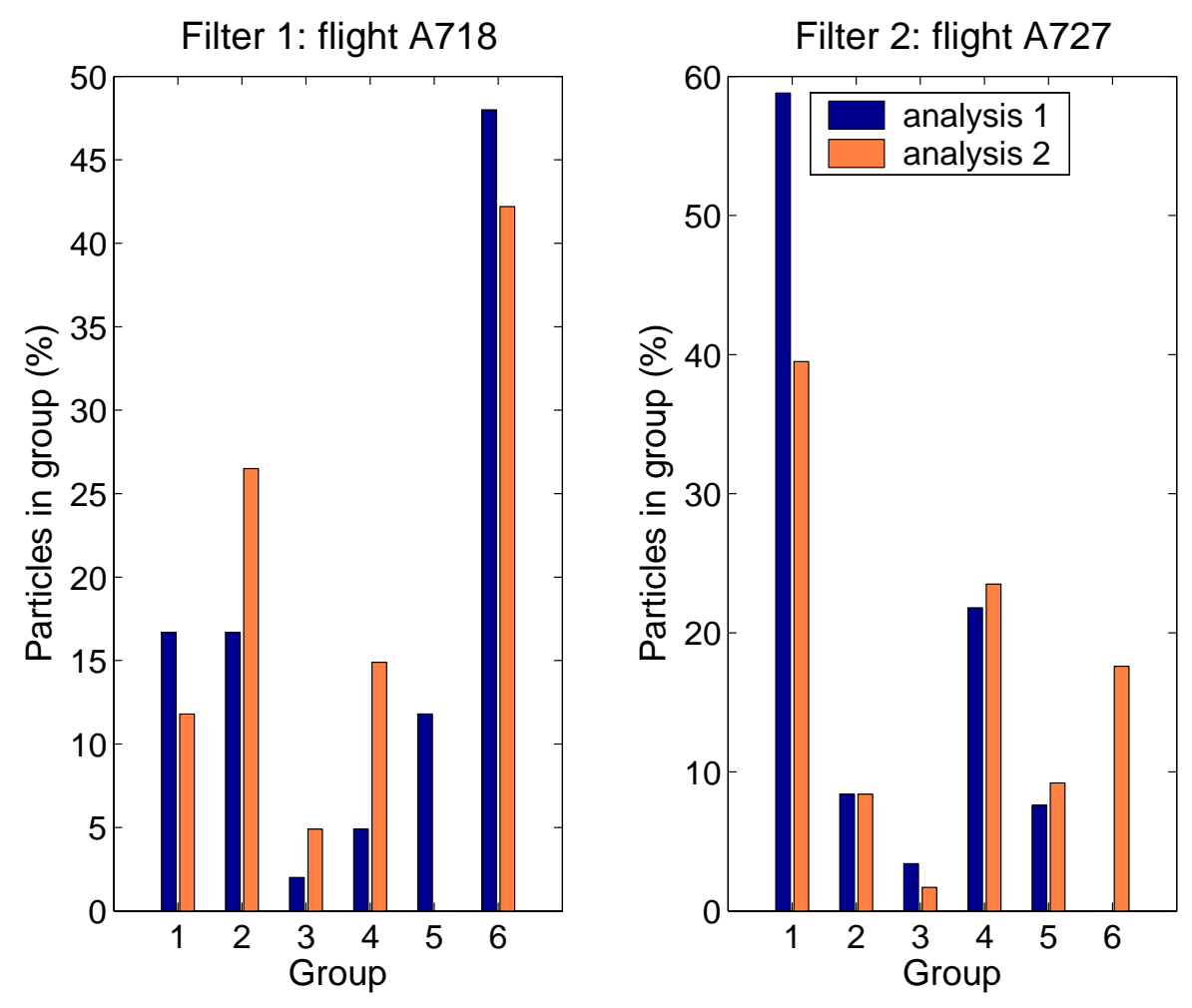

Fig. 1. Percentage of particles falling into each category for the two duplicate samples analyzed on Flight A718 (filter 01 ) and on Flight A727 (filter 02). The abundance of the elements in each group is shown in more detail in Table 5 (for analyses 1).

and $\mathrm{Cr} / \mathrm{Ni}$ ratios derived from EDX peak counts in the range that matched those from our probe. They have thus been discarded from our dataset. Thus, the final dataset is comprised of 601 particles.

An unavoidable limitation of the SEM-EDX analysis in a high vacuum mode is that highly volatile material present in the aerosol particles might evaporate. As a result some particles might shrink or deform, or even disappear completely. Particles potentially affected have not been treated in any specific way as part of the analysis. Therefore the abundances of certain groups should be seen as upper limit.

\section{Results and discussion}

\subsection{Hierarchical cluster analyses}

Hierarchical cluster analysis has been used for identification of the particle groups based on their elemental composition. Following the methodology employed in previous studies (e.g., Artaxo et al., 1992; Liu et al., 2000; Sobanska et al., 2002), the X-ray intensities were used as inputs for the clustering algorithm. For each particle, the elemental X-ray intensities were normalized to the sum of the intensities of detected peaks for each particle (the sum of all characteristic $\mathrm{X}$-rays set equal to $100 \%$ ). Clustering has the advantage of forming natural groups (or classes) without any prior classification of the dataset. The method starts by considering the $n$ data points (in this case, $n$ particles) as individual clusters, and at each step the two more similar particles are merged into a single cluster. The new dataset of $n-1$ objects is again analyzed until the whole data set is reduced to one large class containing all data points. The similarity between two particles was derived using the Euclidian distance coefficient and the Ward's error sum method (Ward, 1963) was employed as the clustering criterion. This criterion proposes that at any stage of the partition the loss of information due to the clustering can be measured by the sum of the square deviations of each point. Other criteria have also been tested, including nearest neighbor and furthest neighbor, but they yielded an unclear separation of the particles.

\subsection{Data representativity}

After screening for possible corruption of the dataset through etching the CVI probe, a second step was to assess the representativity of the samples by performing additional SPA on equal number of residual particles on two previously analyzed filters (collected during INTACC flights A718 and A727). The conceptual principle in analyzing two sets of particles on the same sample is that the surveys of both analyses should provide, in ideal case, equal information about 
Table 1. Percentage of the individual groups found on two single particle analyses performed separately on the same sample of flight A718.

\begin{tabular}{llll}
\hline \multicolumn{1}{c}{ Elements } & $\%$ & \multicolumn{2}{c}{ Analysis 2 } \\
\hline Na-Cr-S & 16.7 & Na-Cr-S & $\%$ \\
$\mathrm{Na}-\mathrm{Si}-\mathrm{S}-\mathrm{Cl}-\mathrm{K}-\mathrm{Ca}$ & 16.7 & $\mathrm{Na}-\mathrm{Si}-\mathrm{S}-\mathrm{Ca}$ & 11.8 \\
$\mathrm{Fe}$ & 2.0 & $\mathrm{Fe}$ & 26.5 \\
$\mathrm{~S}($ low Z $)$ & 4.9 & $\mathrm{~S}$ (low Z) & 4.9 \\
$\mathrm{Mg}-\mathrm{Si}-\mathrm{Ca}$ & 11.8 & - & 14.9 \\
Low Z & 48.0 & Low Z & - \\
\hline Particle & Number of & Particle & 42.2 \\
fraction & particles & fraction & Number of \\
\hline All & 102 & All & particles \\
Submicrometer & 15 & Submicrometer & 102 \\
Supermicrometer & 87 & Supermicrometer & 14 \\
\hline
\end{tabular}

Table 2. Percentage of the individual groups found on two single particle analyses performed separately on the same sample of flight A727.

\begin{tabular}{llll}
\hline \multicolumn{1}{c}{ Elements } & $\%$ & \multicolumn{2}{c}{ Analysis 2 } \\
\hline Cr-Fe-Ni & 58.8 & Crements & $\%$ \\
Na-Mg-S-Cr-Ni & 8.4 & Na-Mg-S-Cr-Ni & 39.5 \\
Low Z & 3.4 & Low Z & 8.4 \\
Al-Si-S & 21.8 & Al-Si-S & 1.7 \\
S (low Z) & 7.6 & Si-S (low Z) & 23.5 \\
- & - & Na-P-S-Ca & 9.2 \\
\hline Particle & Number of & Particle & 17.6 \\
fraction & particles & fraction & Number of \\
\hline All & 119 & All & particles \\
Submicrometer & 79 & Submicrometer & 119 \\
Supermicrometer & 40 & Supermicrometer & 78 \\
\hline
\end{tabular}

the particle population being sampled or the degree of uncertainty in different particle groups abundances.

The assessment of the data representativity for each filter was done by applying cluster analysis on the signal detected with SEM-EDX separately for both datasets. On the first analysis of the filter from flight A718 (referred to as filter 1), 102 particles were analyzed and six groups were identified, while on the second analysis 102 particles were analyzed and the clustering procedure yielded five groups. A group composed of magnesium $(\mathrm{Mg}), \mathrm{Si}$ and calcium $(\mathrm{Ca})$, representing $11.8 \%$ of the particles, is the only group not present in the results of the second analysis (Table 1). The two analyses of 118 particles performed on the filter from flight A727 (referred to as filter 2) yielded similar groups, with the distinction that a group composed of $\mathrm{Na}$ and $\mathrm{S}$, accounting for $17.6 \%$ of the particles analysed in the second set of parti- cles, was not observed during the first analysis (Table 2). With regards to the size distribution of the particles, it was found almost no difference in the number of particles identified in each size fraction on either analysis, as depicted in Tables 1 and 2. We used a two-sample Kolmogorov-Smirnov test to determine whether there were any statistically significant differences in the duplicate samples. The percentage of particles falling into each category for the two duplicate samples was treated as frequency distributions (as shown in Fig. 1). The two-sample Kolmogorov-Smirnov test uses the cumulative distributions for the two variables (the duplicate samples) to compare the proportion of the two variables less than a given value, and test whether the maximum difference in the cumulative distributions is greater than a critical value. The null hypothesis is that the distributions are the same, and the alternate hypothesis in our case is that they are 


\section{INTACC SEM analysis - Cloud samples clustering}
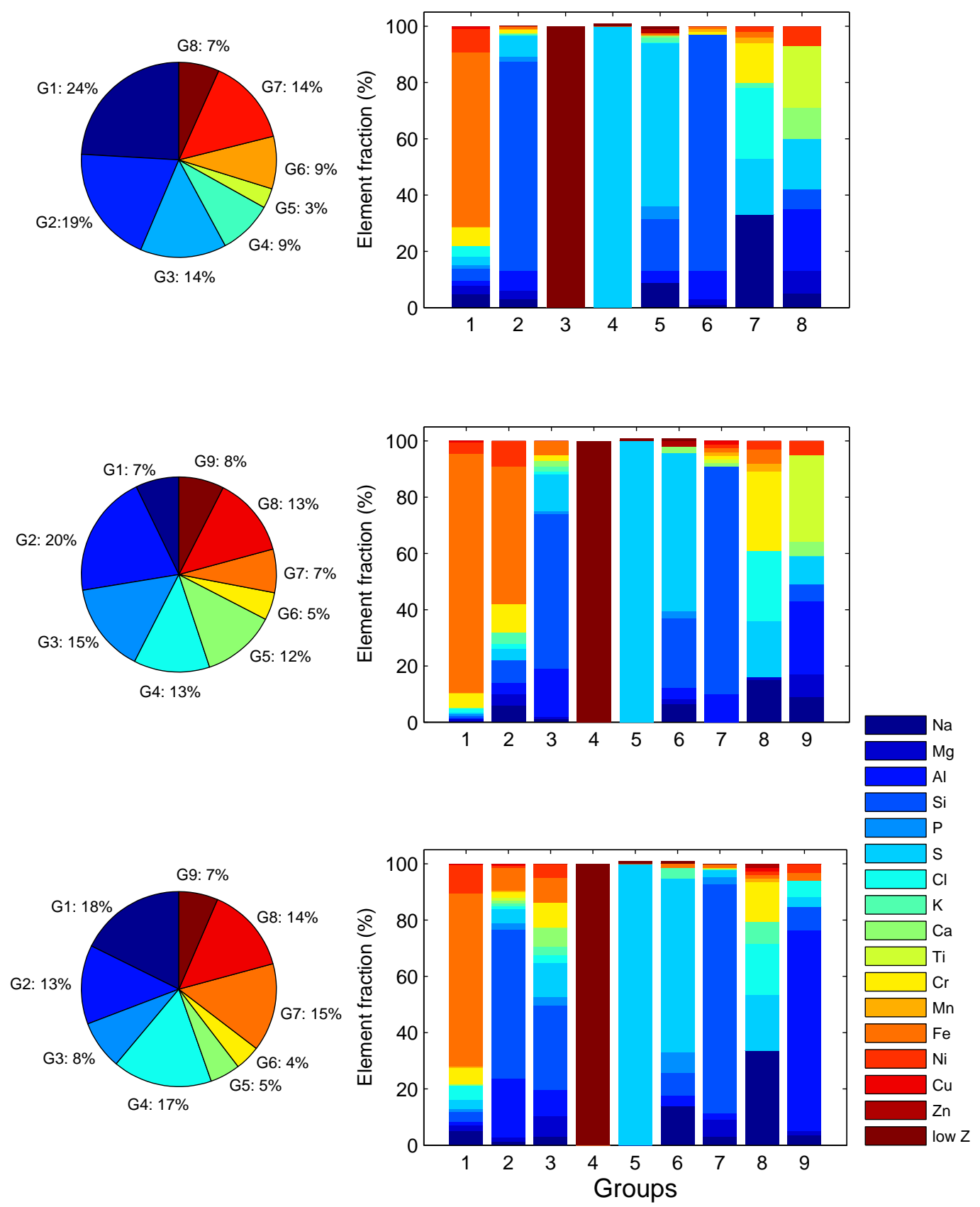

Fig. 2. Hierarchical cluster analysis results for ice crystal residuals. Top row: all particle sizes; middle row: submicrometer fraction, and bottom row: supermicrometer fraction. The color bar shows the abundance of the different elements in each of the clusters, which are shown in more detail in Table 3. Description of the specific particle groups can be found in Sect. 3.4.

different. We used the Matlab ${ }^{\circledR}$ software package to apply the Kolmogorov-Smirnov test at the $\mathrm{p}=0.05$ and 0.01 levels. The null hypothesis was not rejected for any of the cases, in- dicating that there was no statistically significant difference in the duplicate samples. In other words, analyzing about 100 particles or 2 times as much on each sample does not make 
a significant difference for defining distinct particle group abundances.

\subsection{Particle elemental classification}

The cluster analysis has been applied separately to the whole cloud sample population (601 particles) as well as to particles larger and smaller than $1 \mu \mathrm{m}$ (supermicron and submicron fractions, respectively). This allows an efficient way to identify the elements most commonly found in each of the two size fractions. It is noteworthy that the EDX method used in this study can quantify only elements with atomic number larger or equal to $11(\mathrm{Na})$. Light elements, like $\mathrm{C}$, nitrogen (N) and $\mathrm{O}$ cannot be quantified because of the carbon coating and polycarbonate nature of the filter. Particles that did not contain significant amounts of detectable elements with $\mathrm{Z}>11$ are referred to as "low-Z" particles. Although hierarchical cluster analysis is an objective technique, in the sense that the distance between elements and the clustering criteria are based on mathematical measures, the interpretation of the results is subjective. The grouping is based on the arbitrary selection of the number of clusters present in the dataset. In this study, the choice was based on the chemical composition of each cluster (expressed as percentages of the elemental Xray intensities of each element in the cluster) as well as the morphology of the particles.

\subsection{Global classification}

Eight different particle groups could be identified in the combined dataset from the cloud residual samples (601 particles). Table 3 summarizes the dominant clusters derived from all filter data with the average composition for the elements found in each cluster. The values were obtained by averaging over all samples. It is also shown how the particles are distributed into sub- and supermicrometer fractions within each defined group. Figure 2 shows the average relative abundance of the different particle types as well as for the suband supermicrometer fractions. Examples of secondary electron images of residual ice crystal particles observed during INTACC are shown in Fig. 3.

\subsubsection{Fe-rich (Group 1)}

The Fe-rich group is the largest cluster and constitutes almost $25 \%$ of the particles analyzed. These particles are characterized by the presence of Fe comprising roughly $60 \%$ of the characteristic X-ray spectrum. They appear mostly in the submicron fraction as two distinct sub-groups. One group contains impurities as $\mathrm{Na}(6 \%), \mathrm{Si}(8 \%), \mathrm{Cr}(8 \%)$ and $\mathrm{Ni}$ (9\%) in addition to $\mathrm{Fe}(48 \%)$, and another has characteristics of pure iron oxide. Even though the latter holds some $\mathrm{Cr}$ and $\mathrm{Ni}$, their proportions are not in the range of those from the CVI probe, and are not thus regarded as a result of etching processes, as discussed in Sect. 2.2.

\subsubsection{Aluminosilicates (Group 2)}

This is the second largest cluster group and constitutes almost $20 \%$ of the particles analyzed. Particles in this group are characterized by the presence of aluminum $(\mathrm{Al})(16 \%)$, $\mathrm{Si}(49 \%)$ and $\mathrm{Fe}(7 \%)$, whose X-rays sum up to more than $80 \%$ of the characteristic X-ray signal detected. 63 particles appear in the submicron fraction while 56 are present in the supermicrometer fraction. The supermicrometer fraction is further divided into two sub-groups, one of which is made up of $\mathrm{Al}(21 \%), \mathrm{Si}(53 \%)$ and $\mathrm{Fe}(8 \%)$, while the other shows a more complex combination of $\mathrm{Mg}, \mathrm{Al}, \mathrm{S}, \mathrm{Ca}, \mathrm{Cr}$ and $\mathrm{Fe}$ in addition to $\mathrm{Si}(29 \%)$.

\subsubsection{Low-Z particles (Group 3)}

Low- $Z(Z<11)$ particles comprise $14.3 \%$ of the total number of particles analyzed. "Low-Z" and "organic" will be used interchangeably here and will denote particles that do not contain significant amounts of detectable elements with $\mathrm{Z}>11$. Even though EDX analysis can identify elements lighter than $\mathrm{Na}$, the polycarbonate nature of the filter hinders using these results because it is difficult to distinguish between C-O-N peaks from the particles and from the filter substrate. Inspection of the X-ray spectra only allows differentiating between particle classes (e.g., between minerals, calcites, sea salts and low-Z elements). The X-ray spectra of this kind of particles were characterized by background signal without significant elemental peaks (see Fig. 3F). Spectra with this feature have been described in the literature as typical for organic and biological material (e.g., Mamane and Noll, 1985; Xhoffer et al., 1991). Ascertaining the organic nature of the particles turns out to be impossible because of these limitations, but previous studies have suggested that fly ash, soot agglomerates, biogenic debris and ammonium nitrate can compose this group (Xhoffer et al., 1991; Krejci et al., 2004). We have ruled out the presence of ammonium nitrate since the cases whereby the low- $\mathrm{Z}$ particles were identified were linked to airmass trajectories of marine origin (see Sect. 3.5). Ammonium nitrate is a continental phenomenon with concentrations that decreases from coast to open sea. Local contributions have also been ruled out since over most of Scandinavia annual average nitrate concentrations are lower than $0.5 \mu \mathrm{g} / \mathrm{m}^{3}$ (Schaap et al., 2002). Based on this and on the indirect evidence presented in this paper, we can state that the particles in this group are organic aerosol particles. Low-Z particles appear equally distributed in both size modes studied here, with 43 particles presenting the supermicrometer mode and 44 in the submicrometer. Inspection of the morphology reveals that there were a variety of shapes and textures among the low-Z particles. Some of them had amorphous shape with small spheres attached to one another to form relatively large flakes of soot. 

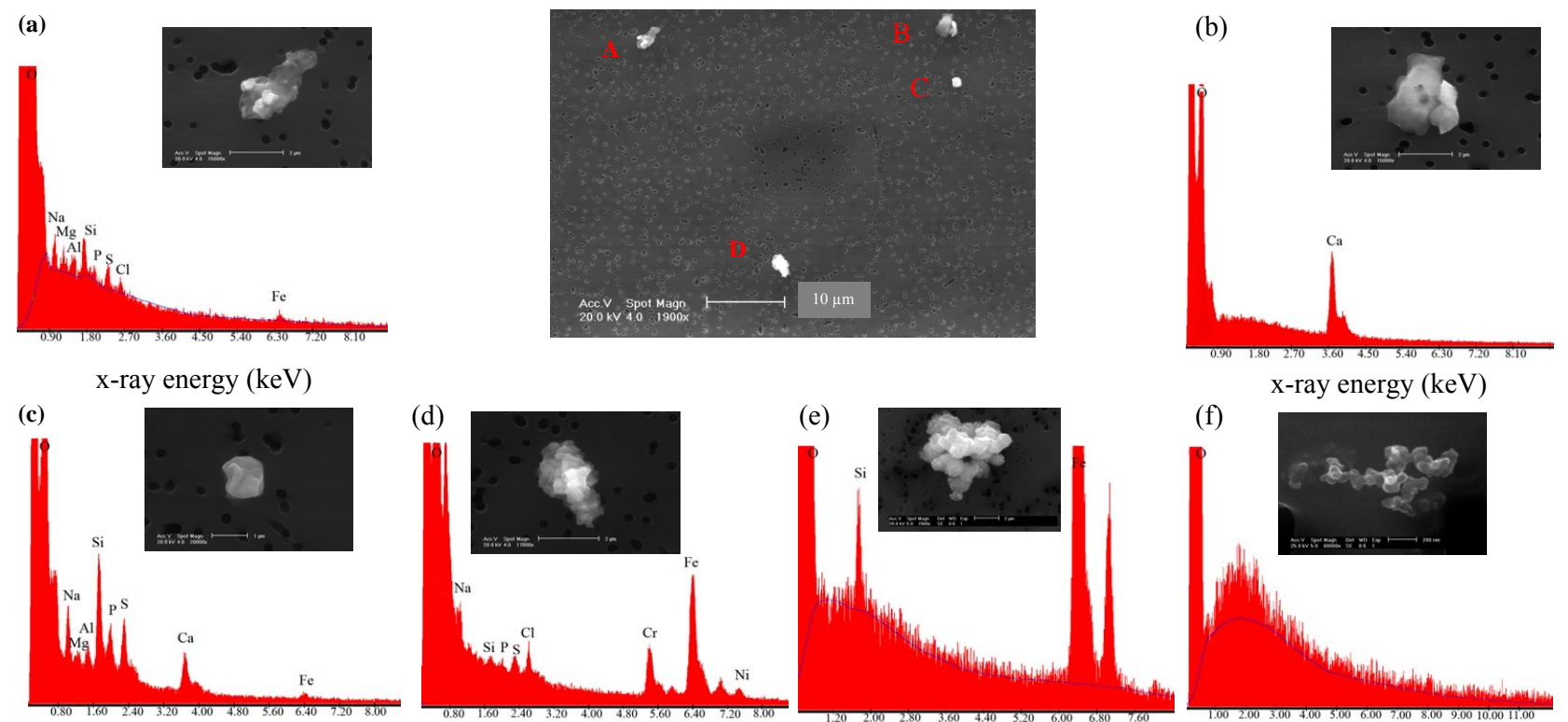

x-ray energy $(\mathrm{keV})$ x-ray energy $(\mathrm{keV})$

x-ray energy $(\mathrm{keV})$

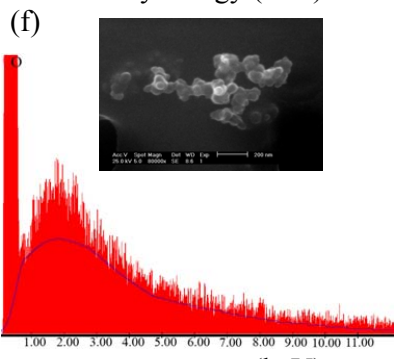

Fig. 3. Secondary electron images and EDX spectra of residual ice crystals collected during INTACC. Inserts (A), (B), (C), and (D), are detailed micrographs of the larger micrograph shown in the upper row, middle column. Inserts (E) and (F) do not appear in the larger micrograph.

Table 3. Average relative abundance (\%) and composition of the individual particle groups $(\mathrm{G})$ of ice crystal residual collected on six INTACC flights. The numbers in parenthesis are mean percent of X-ray counts. Only elements with number of counts larger than 5\% are shown.

\begin{tabular}{|c|c|c|c|c|c|c|}
\hline G & All particles & & Submicrometer & & Supermicrometer & \\
\hline & $\begin{array}{l}\text { Elements ( } \% \text { number } \\
\text { of X-ray counts) }\end{array}$ & $\%$ & $\begin{array}{l}\text { Elements (\% number } \\
\text { of X-ray counts) }\end{array}$ & $\%$ & $\begin{array}{l}\text { Elements (\% number } \\
\text { of X-ray counts) }\end{array}$ & $\%$ \\
\hline 1 & $\mathrm{Na}(5) \mathrm{Si}(5) \mathrm{Cr}(7) \mathrm{Fe}(58) \mathrm{Ni}(8)$ & 24.1 & $\begin{array}{l}\mathrm{Cr}(5) \mathrm{Fe}(85) \mathrm{Ni}(4) \\
\mathrm{Na}(6) \mathrm{Si}(8) \\
\mathrm{Ni}(9)\end{array}$ & $\begin{array}{c}7.2 \\
20.4\end{array}$ & $\mathrm{Na}(6) \mathrm{Cl}(6) \mathrm{Cr}(6) \mathrm{Fe}(59) \mathrm{Ni}(10)$ & 17.7 \\
\hline 2 & $\operatorname{Al}(16) \mathrm{Si}(49) \mathrm{S}(8) \mathrm{Fe}(7)$ & 19.5 & $\operatorname{Al}(17) \operatorname{Si}(50) \mathrm{S}(13) \mathrm{Fe}(5)$ & 14.9 & $\begin{array}{l}\operatorname{Al}(21) \operatorname{Si}(53) \operatorname{Fe}(8) \\
\operatorname{Mg}(7) \quad \operatorname{Al}(9) \quad \operatorname{Si}(29) \quad \mathrm{S}(10) \\
\mathrm{Ca}(7) \operatorname{Cr}(9) \operatorname{Fe}(8)\end{array}$ & $\begin{array}{c}13.1 \\
8.1\end{array}$ \\
\hline 3 & Low Z (100) & 14.3 & Low Z (100) & 12.6 & Low Z (100) & 16.5 \\
\hline 4 & $\mathrm{~S}(100)$ (low Z) & 9.0 & S(99) (low Z) & 12.3 & S(100) (low Z) & 5.0 \\
\hline 5 & Si(24) S(63) (low Z) & 3.3 & $\mathrm{Na}(6) \mathrm{Si}(26) \mathrm{S}(58)($ low Z $)$ & 4.6 & $\mathrm{Na}(14) \mathrm{Si}(7) \mathrm{S}(62)($ low Z) & 4.2 \\
\hline 6 & $\operatorname{Si}(84)$ & 8.7 & $\operatorname{Al}(10) \operatorname{Si}(81)$ & 7.2 & $\operatorname{Mg}(6) \operatorname{Si}(82)$ & 14.6 \\
\hline 7 & $\mathrm{Na}(33) \mathrm{S}(20) \mathrm{Cl}(25) \mathrm{Cr}(14)$ & 14.4 & $\begin{array}{l}\mathrm{Na}(15) \quad \mathrm{S}(20) \quad \mathrm{Cl}(25) \\
\mathrm{Cr}(28) \mathrm{Fe}(5)\end{array}$ & 13.0 & $\begin{array}{llll}\mathrm{Na}(34) & \mathrm{S}(20) & \mathrm{Cr}(18) & \mathrm{K}(8) \\
\mathrm{Cr}(14) & & & \end{array}$ & 14.3 \\
\hline 8 & $\begin{array}{l}\mathrm{Na}(5) \operatorname{Mg}(8) \mathrm{Al}(22) \mathrm{Si}(7) \mathrm{S}(18) \\
\mathrm{Ca}(11) \mathrm{Ti}(22) \mathrm{Ni}(7)\end{array}$ & 6.7 & $\begin{array}{l}\mathrm{Na}(9) \operatorname{Mg}(8) \operatorname{Al}(26) \operatorname{Si}(6) \\
\mathrm{S}(10) \mathrm{Ca}(5) \operatorname{Ti}(31) \mathrm{Ni}(5)\end{array}$ & 8.0 & $\mathrm{Al}(71) \mathrm{S}(4) \mathrm{Cl}(7)$ & 6.5 \\
\hline
\end{tabular}

\subsubsection{Si and S-enriched low-Z particles (Groups 4 and 5)}

About $12 \%$ of the particles analyzed are composed of light atomic number elements and $\mathrm{Si}$-, or S-bearing compounds.
The X-ray spectra of this kind of particles were characterized by high background signal, that is, without significant elemental peaks, except for weak emission lines of S (Group 4) and both Si and S (Group 5). Particles with weak emission 
line corresponding to $\mathrm{S}$ were found mostly in the submicron fraction. It is difficult to establish their sources, but one possibility is that they may have biological origin. It has been observed that biological particles (composed of light elements such as hydrogen (H), C, O and N) with their complex morphology and wet surfaces provide suitable nucleating surface for $\mathrm{SO}_{2}$ absorption and conversion to sulfate, as well as deposition of submicrometer sulfates on the surface of these particles (Mamane and Noll, 1985).

\subsubsection{Si-rich (Group 6)}

This group of more pure silicates (probably quartz $\mathrm{SiO}_{2}$ ) accounts for $9 \%$ of the particles analyzed having composition of Si larger than $80 \%$. The remaining $20 \%$ is distributed among $\mathrm{Na}, \mathrm{Mg}, \mathrm{Al}$, phosphorus (P) and S. 36 particles appeared in the coarse fraction and 17 in the fine fraction. This cluster does not contain significant levels of $\mathrm{S}$, as detected in other groups dominated by minerals (like group 8 ). The explanation why some minerals are more susceptible to sulfate enrichment than others can lie on the chemistry of the particle surface as well as on the time available for the reaction as well as on source region. Only particles with the appropriate surface chemistry and which were suspended in the air for a long period (and thus, probably subject to cloud processing) can react with $\mathrm{SO}_{2}$ (see e.g., Reid et al., 2003, and references therein about Saharan dust).

\subsubsection{Transformed sea-salt particles (Group 7)}

The sodium, chlorine and chromium-rich group comprising $14 \%$ of the analyzed particles is also rich in S. These particles are identified as aged sea salt and can be interpreted as a result of cloud processing. Fitzgerald (1991) has stated that marine aerosol particles cycle several times through cloud formation and evaporation processes, leading to sulfur excess in the particles and enrichment of several compounds at individual particle level. In this study, $13 \%$ of the submicrometer particles belong to this group, while $14.3 \%$ make up the supermicrometer fraction.

\subsubsection{Mixed particles (Group 8)}

This small group accounts for $7 \%$ of the particles analyzed and appears in both sub- and supermicrometer fractions. They show a varied combination of $\mathrm{Na}, \mathrm{Mg}, \mathrm{Al}, \mathrm{Si}, \mathrm{Ca}$ and Ti. They may result from an aggregation of particles in the atmosphere. The most correct way of interpreting these groups is probably by viewing them as a continuum of clay minerals rather than individual species. In addition to these elements, $\mathrm{S}$ contributes with about $18 \%$ to the average composition indicating that these are presumably aged particles. Mamane et al. (1980) and Levin et al. (1996) showed that dust particles generated in the desert areas could be transported over distances of hundreds and even thousands of kilometers, without resuspension and sulfate could be formed on the surface of mineral dust particles. Cloud processes, such as gas scavenging and liquid phase oxidation of $\mathrm{SO}_{2}$ and coagulation of drops containing sulfate with those containing mineral dust, are responsible for the sulfate coating (Reid et al., 2003).

\subsection{Particle classes and association to airmass history}

The airmass history for the INTACC missions was obtained using 5-day back trajectory from the HYSPLIT model of the National Oceanic and Atmospheric Administration (NOAA) (Draxler and Rolph, 2003). During the INTACC mission flights investigated here the prevailing airmasses arriving at the measurement area originated over North America, North Atlantic and Arctic. A clean marine airmass is thus defined as trajectories confined to the Atlantic and Arctic Oceans and/or with source altitude in the free troposphere (FT), having traveled under unperturbed conditions for the entire length of the 5-day transport time. Mixed airmass refers to trajectories that originated or traveled over continental areas and with source altitudes in the continental boundary layer (BL).

The trajectories were calculated for locations were the filters were exposed (based on information from the in-flight logbook) with varying arrival height in order to cover the flight altitudes, which ranged from 4 to $8 \mathrm{~km}$. The trajectory classification is summarized in Table 4 . In order to assess the geographical variability of the airmasses, trajectories were obtained for other points along the flight track. The results (not shown here) indicate that in some cases there is a considerable difference in the origin of the airmass between those arriving at F4 air base in Östersund and other points along the flight track. Hence any attempt to link airmass history with residual composition should take into account the location where the filter has been exposed.

Results of the single particle analysis from individual samples chosen to illuminate the possible relations between airmass history and ice formation are presented below.

\subsubsection{Clean airmass}

\section{a. Flight 718}

The filter of flight A718 was exposed over a region south of F4 air base and over Norway. The trajectories arriving between 4 and $6 \mathrm{~km}$ originated in the marine boundary layer (MBL) over the North Atlantic and $24 \mathrm{~h}$ before reaching the measurement area traveled over the UK. Because the height of these trajectories was in the FT as they passed over the UK, we assume that they were not recently affected by any anthropogenic pollution source and can be classified as clean airmass. The cloud residual clusters found in the filter collected during this flight were low-Z (48\%), silicates (12\%), low-Z coated with S (5\%), aged sea salt $(17 \%)$, aged chromine-sodium compounds $(17 \%)$ and $\mathrm{Fe}$ (2\%) (Table 5). 
Table 4. Summary of INTACC flights used in this study with the type of airmasses reaching the arrival points along the flight track.

\begin{tabular}{|c|c|c|c|c|c|}
\hline Flight & Date & $\begin{array}{l}\text { Arrival } \\
\text { height } \\
(\mathrm{Km})\end{array}$ & Origin & Arrival point & Travelling over \\
\hline A718 & $1 \mathrm{Oct}$ & $\begin{array}{l}4 \\
5 \\
6\end{array}$ & $\begin{array}{l}\text { BL } \\
\text { BL } \\
\text { FT }\end{array}$ & $61^{\circ} \mathrm{N}, 6.5^{\circ} \mathrm{E}$ & $\begin{array}{l}\text { North Atlantic and } \\
\text { UK }\end{array}$ \\
\hline A720 & 3 Oct & $\begin{array}{l}6 \\
7 \\
8\end{array}$ & $\begin{array}{l}\text { FT } \\
\text { FT } \\
\text { FT }\end{array}$ & $63.2^{\circ} \mathrm{N}, 14.3^{\circ} \mathrm{E}$ & $\begin{array}{l}\text { North } \begin{array}{c}\text { America, } \\
\text { North Atlantic and } \\
\text { UK }\end{array}\end{array}$ \\
\hline A723 & $7 \mathrm{Oct}$ & $\begin{array}{l}6 \\
7 \\
8\end{array}$ & $\begin{array}{l}\text { BL } \\
\text { FT } \\
\text { FT }\end{array}$ & $62.3^{\circ} \mathrm{N}, 4.6^{\circ} \mathrm{E}$ & $\begin{array}{l}\text { North America and } \\
\text { North Atlantic }\end{array}$ \\
\hline A724 & 8 Oct & $\begin{array}{l}6 \\
7 \\
8\end{array}$ & $\begin{array}{l}\text { FT } \\
\text { FT } \\
\text { FT }\end{array}$ & $62.7^{\circ} \mathrm{N}, 9.2^{\circ} \mathrm{E}$ & $\begin{array}{l}\text { North America and } \\
\text { North Atlantic }\end{array}$ \\
\hline A727 & 13 Oct & $\begin{array}{l}5 \\
6 \\
7\end{array}$ & $\begin{array}{l}\text { BL } \\
\text { FT } \\
\text { FT }\end{array}$ & $67.7^{\circ} \mathrm{N}, 19^{\circ} \mathrm{E}$ & Western Russia \\
\hline
\end{tabular}

\subsubsection{Mixed airmass}

a. Flights A720 and A724

Flights A720 and A724 were affected by mixed airmasses that originated over North America. Mineral dust in the form of $\mathrm{Fe}$-, Si-rich particles and aluminosilicates account for about $88 \%$ and $92 \%$ of crustal elements in flights A720 and A724, respectively. Low-Z elements represented a very small fraction of the dataset in both flights (Table 5).

\section{b. Flight A723}

The trajectories arriving at $6 \mathrm{~km}$ originated in the MBL of the northeastern coast of the USA and Canada and ascended steadily in the atmosphere as it moved over the North Atlantic. It was largely influenced by the MBL during the first two days over the ocean and possibly by continental sources earlier. The trajectories arriving at 7 and $8 \mathrm{~km}$ started over the USA and Canada and were confined to the FT.

During this flight, two filters were exposed at almost the same location close to the Norwegian coast, but in opposite flight direction. Filter 5 was sampled upwind of the cloud, on stepwise descent from $8.5-6.8 \mathrm{~km}$, thereafter filter 6 was exposed downwind of the cloud, following a similar stepwise descent.
The particles found on filter 6 shows characteristics of marine influenced airmass, with $31 \%$ of the dataset containing $\mathrm{Na}-\mathrm{Cl}$, and about $36 \%$ made up of low-Z particles. The third largest group $(13.5 \%)$ was formed by $\mathrm{Si}, \mathrm{Na}$ (not associated with $\mathrm{Cl}$ ) and S. About $19 \%$ of the particles were composed of some kind of crustal material (Table 5).

Mineral dust is, however, prevalent on filter 5, with Fe-rich cluster comprising $34.9 \%$ of the observations, and aluminosilicates accounting for $27.4 \%$. Other minor groups of mineral dust are Fe-Mn-Cr $(2.8 \%)$ and Al-Si coated with $\mathrm{S}(9.4 \%)$. Low-Z particles contribute with $15 \%$ and sea-salt with $10.4 \%$ (Table 5).

\section{c. Flight A727}

Flight A727 was performed along a south-north axis, extending as far as $67.7^{\circ} \mathrm{N}, 19^{\circ} \mathrm{E}$ (where the filter was exposed). The trajectories reaching the measurement region originated over Turkey, traveled within the BL over Russia, thereafter it ascended reaching northern Scandinavia. The terrestrial influence on the ice crystals composition is clearly seen through the SPA clustering for this flight. The abundance of mineral dust in this sample is $89 \%$, while the rest $11 \%$ is comprised of low-Z and low-Z S-bearing particles (Table 5). 
Table 5. Average relative abundance (\%) and composition of the individual particle groups (G) of ice crystal residual collected on INTACC flights affected by clean and mixed airmasses. The numbers in parenthesis are mean percent of X-ray counts. Only elements with number of counts larger than $5 \%$ are shown.

\begin{tabular}{|c|c|c|c|c|c|c|c|c|}
\hline Flight & G1 & $\mathrm{G} 2$ & G3 & G4 & G5 & G6 & G7 & G8 \\
\hline A718 & 16.7 & 16.7 & 2.0 & 4.9 & 11.8 & 48.0 & - & - \\
\hline (\% number of $X$-ray counts) & $\begin{array}{l}\mathrm{Na}(40) \\
\mathrm{S}(19) \\
\mathrm{Cr}(35)\end{array}$ & $\begin{array}{l}\mathrm{Na}(27) \\
\mathrm{Si}(8) \\
\mathrm{S}(25) \\
\mathrm{Cl}(10) \\
\mathrm{K}(6) \\
\mathrm{Ca}(6) \\
\mathrm{Cr}(6)\end{array}$ & $\mathrm{Fe}(85)$ & $\begin{array}{l}\mathrm{S}(100) \\
(\text { low Z) }\end{array}$ & $\begin{array}{l}\operatorname{Mg}(9) \\
\operatorname{Si}(71)\end{array}$ & $\begin{array}{l}\text { Low Z } \\
(100)\end{array}$ & & \\
\hline A720 & 11 & 1.8 & 17.4 & 4.6 & 2.8 & 24.8 & 27.5 & 10.1 \\
\hline (\% number of X-ray counts) & $\begin{array}{l}\mathrm{Na}(6) \\
\mathrm{Al}(11) \\
\mathrm{Si}(34) \\
\mathrm{P}(7) \\
\mathrm{S}(33)\end{array}$ & $\begin{array}{l}\mathrm{S}(41) \\
\mathrm{Ca}(56)\end{array}$ & $\begin{array}{l}\mathrm{Na}(8) \\
\mathrm{Mg}(7) \\
\mathrm{Al}(7) \\
\mathrm{Si}(14) \\
\mathrm{S}(7) \\
\mathrm{Cr}(14) \\
\mathrm{Fe}(31)\end{array}$ & $\begin{array}{l}\mathrm{Na}(21) \\
\mathrm{Mg}(24) \\
\mathrm{Al}(6) \\
\mathrm{Si}(8) \\
\mathrm{S}(5) \\
\mathrm{Fe}(24) \\
\mathrm{Ni}(9)\end{array}$ & $\begin{array}{l}\mathrm{Al}(66) \\
\mathrm{Si}(7) \\
\mathrm{S}(7) \\
\mathrm{Cl}(9)\end{array}$ & $\begin{array}{l}\mathrm{Al}(17) \\
\mathrm{Si}(62) \\
\mathrm{Fe}(7)\end{array}$ & $\begin{array}{l}\mathrm{Si}(6) \\
\mathrm{Cl}(6) \\
\mathrm{Cr}(8) \\
\mathrm{Fe}(58) \\
\mathrm{Ni}(10)\end{array}$ & $\begin{array}{l}\text { Low Z } \\
(100)\end{array}$ \\
\hline A723 (Filter 5) & 9.4 & 2.8 & 8.5 & 10.4 & 27.4 & 6.6 & 34.9 & - \\
\hline (\% number of X-ray counts) & $\begin{array}{l}\mathrm{Al}(10) \\
\mathrm{Si}(15) \\
\mathrm{P}(7) \\
\mathrm{S}(49) \\
\mathrm{Ca}(11)\end{array}$ & $\begin{array}{l}\mathrm{S}(12) \\
\mathrm{Cr}(62) \\
\mathrm{Mn}(8) \\
\mathrm{Fe}(12)\end{array}$ & $\begin{array}{l}\mathrm{S}(100) \\
(\text { Low Z) }\end{array}$ & $\begin{array}{l}\mathrm{Na}(48) \\
\mathrm{S}(11) \\
\mathrm{Cl}(40)\end{array}$ & $\begin{array}{l}\mathrm{Al}(14) \\
\mathrm{Si}(58) \\
\mathrm{S}(12)\end{array}$ & $\begin{array}{l}\text { Low Z } \\
(100)\end{array}$ & $\begin{array}{l}\mathrm{Na}(5) \\
\mathrm{Cr}(6) \\
\mathrm{Fe}(68) \\
\mathrm{Ni}(8)\end{array}$ & \\
\hline A723 (Filter 6) & 31.1 & 6.8 & 6.8 & 5.4 & 13.5 & 6.8 & 29.7 & - \\
\hline (\% number of X-ray counts) & $\begin{array}{l}\mathrm{Na}(24) \\
\mathrm{S}(16) \\
\mathrm{Cl}(58)\end{array}$ & $\begin{array}{l}\mathrm{Na}(32) \\
\mathrm{Mg}(11) \\
\mathrm{S}(7) \\
\mathrm{Ca}(28) \\
\mathrm{Zn}(7)\end{array}$ & $\begin{array}{l}\mathrm{P}(6) \\
\mathrm{Cr}(5) \\
\mathrm{Fe}(73) \\
14(6)\end{array}$ & $\begin{array}{l}\mathrm{Na}(10) \\
\mathrm{Ti}(83)\end{array}$ & $\begin{array}{l}\mathrm{Na}(6) \\
\mathrm{Al}(5) \\
\mathrm{Si}(65) \\
\mathrm{S}(14)\end{array}$ & $\begin{array}{l}\text { Low Z } \\
(100)\end{array}$ & $\begin{array}{l}\operatorname{Si}(6) \\
\mathrm{S}(82) \\
(\text { low Z) }\end{array}$ & \\
\hline A724 & 13.3 & 0.9 & 32.7 & 2.6 & 5.3 & 1.8 & 43.4 & - \\
\hline (\% number of X-ray counts) & $\begin{array}{l}\mathrm{Na}(14) \\
\mathrm{Mg}(16) \\
\mathrm{Si}(6) \\
\mathrm{Cl}(7) \\
\mathrm{Cr}(8) \\
\mathrm{Fe}(23) \\
\mathrm{Ni}(18)\end{array}$ & $\operatorname{Ti}(100)$ & $\begin{array}{l}\mathrm{Al}(17) \\
\mathrm{Si}(56) \\
\mathrm{Fe}(9)\end{array}$ & $\begin{array}{l}\mathrm{Al}(71) \\
\mathrm{Si}(8) \\
\mathrm{Cl}(6)\end{array}$ & $\begin{array}{l}\mathrm{Si}(15) \\
\mathrm{S}(40) \\
\mathrm{Ca}(34)\end{array}$ & $\begin{array}{l}\text { Low Z } \\
(100)\end{array}$ & $\begin{array}{l}\mathrm{Si}(5) \\
\mathrm{Cl}(5) \\
\mathrm{Cr}(7) \\
\mathrm{Fe}(60) \\
\mathrm{Ni}(9)\end{array}$ & \\
\hline A727 & 58.8 & 8.4 & 3.4 & 21.8 & 7.6 & - & - & - \\
\hline (\% number of X-ray counts) & $\begin{array}{l}\mathrm{Cr}(8) \\
\mathrm{Fe}(82)\end{array}$ & $\begin{array}{l}\mathrm{Na}(27) \\
\mathrm{Al}(5) \\
\mathrm{Si}(6) \\
\mathrm{S}(28) \\
\mathrm{Cr}(17) \\
\mathrm{Fe}(6)\end{array}$ & $\begin{array}{l}\text { Low Z } \\
(100)\end{array}$ & $\begin{array}{l}\mathrm{Al}(12) \\
\mathrm{Si}(70) \\
\mathrm{S}(10)\end{array}$ & $\begin{array}{l}\mathrm{S}(96) \\
(\text { low Z) }\end{array}$ & & & \\
\hline
\end{tabular}




\section{Discussions}

The results of the SPA of cloud residuals collected on INTACC flights affected by different airmasses are now put into a broader context and discussed in light of the cloud phase for the same missions reported by Field et al. (2001). They have shown that the relatively warm regime (temperatures $>-35^{\circ} \mathrm{C}$ ) observed during INTACC reduced homogeneous freezing rates while heterogeneous ice nucleation prevailed. They described the microphysical characteristics of five INTACC flights carried out in wave clouds at approximately the same environmental temperature $\left(\mathrm{T} \sim-27^{\circ} \mathrm{C}\right)$ and showed that the cloud investigated during flight A718 was the only case where no ice formation was observed. A connection between cloud phase and the chemical nature of the aerosol was suggested by Field et al. (2001). Interestingly, in the SPA results presented in this work, A718 was the case with the highest concentration of low- $\mathrm{Z}$ particles among the cases investigated. Given that the flights were performed under similar thermodynamical conditions, the composition of the aerosol particles on which the cloud droplets were formed is suggested as a possible important factor that determines the cloud phase.

It is well established that oceans are a major source of organic compounds (e.g., Novakov et al., 1997; Rivera-Carpio et al., 1996) and the presence of surfactants, such as protein degradation products in marine aerosol, was shown by Blanchard (1964). It was found by Blanchard (1964) that surface-active organic material is adsorbed or scavenged by the bubbles as they rise toward the water surface. Novakov et al. (1997) have shown that the volatility properties of the marine organic aerosols are different from those observed in, for example, continental combustion-influenced regions and renders these particles active CCN. In their study, $70 \%$ of the marine organic carbon mass was found to be water-soluble compounds, such as fatty and carboxylic acids. Matsumoto et al. (1997) found that not only sulfates but also water-soluble organic salts (formate, acetate, oxalate and methanesulphonic acid) were dominant in fine marine aerosols (aerodynamic diameter $<1.1 \mu \mathrm{m}$ ) and that there was a correlation between the concentration of these compounds and $\mathrm{CCN}$ concentrations. Moreover, organic residuals were also identified in cloud condensation nuclei of marine stratiform clouds in anthropogenically-influenced air during the Monterey Area Ship Track experiment (MAST) (de Book et al., 2000; Noone et al., 2000; Russell et al., 2000).

The apparent ability of organic aerosol to serve as cloud condensation nuclei can be explained through two pathways. The first is that a fraction of these particles may be hydrophilic and have thus a critical supersaturation similar to that of ammonium sulfate. A second possibility is that organic aerosols are inherently inactive and that condensation of $\mathrm{H}_{2} \mathrm{SO}_{4}$ vapor, or some other water-soluble species, onto these particles makes them efficient CCN (Novak and Penner, 1993).
Since the airmass of flight A718 originated in the MBL over the North Atlantic, it is reasonable to suggest that the source of these organic particles is the marine region. They may have been injected in the atmosphere through sea spray and bubble bursting or derived from organic vapor emissions from the surfactant layer, which undergoes gas-to-particle conversion (nucleation and condensation). Not all marine organic aerosol particles act as $\mathrm{CCN}$, but if the organic particles observed on this flight have had solubility similar to that reported by Novakov et al. (1997), this suggests that they may be a major contributor to the formation of cloud droplets. On the other hand, Cziczo et al. (2004) have shown that organic components do not partition equally to the ice and aqueous phases. Instead, organic-rich particles preferentially remain unfrozen and we therefore believe that the organic nature of the residual particles is the main reason why ice crystals have not been observed on this flight. It is uncertain how this can happen, but Yeh and Feeney (1996) suggested several mechanisms by which antifreeze proteins, such as those found in polar fish that survive freezing conditions, inhibit bulk ice formation. Cziczo et al. (2004) proposed that atmospheric aerosols contain organic molecules with similar properties as those found in the marine biota, and which can lead to ice growth inhibition as well as to altered growth aspects. As stated before, we are unable to specify the kind of organic material present, but with respect to previous measurements (e.g., Krejci et al., 2004) and the data shown here we can speculate that similar anti-freezing properties may apply to the low- $Z$ residual particles.

Because the size of the particles analyzed was restricted by the detection limit of the SEM (about $0.1 \mu \mathrm{m}$ ), the data shown here represents a minor fraction of residuals, as the majority of them (in terms of number) are smaller than $100 \mathrm{~nm}$ diameter. However this may not impair the interpretation of the results found, as in the temperature regime observed during the experiment, the aerosols were first activated into liquid cloud droplet with subsequent formation of ice crystal. This way, a substantial fraction of the aerosol volume, which is dominated by particles larger than $0.1 \mu \mathrm{m}$, was incorporated in the cloud droplets.

Even though the above analysis is a simple study, our SPA results together with the microphysical analysis of Field et al. (2001) complement each other and support the hypothesis of ice crystal inhibition induced by organic material as well as a relationship among airmass origin, particle composition and cloud phase.

\section{Summary and concluding remarks}

A survey of 609 cloud residual particles larger than $0.1 \mu \mathrm{m}$ diameter, collected in orographic clouds over Scandinavia, were analyzed using the SEM-EDX technique. Mineral dust in the form of iron $(24.1 \%)$ and aluminosilicates (19.5\%) followed by low-Z particles (23.3\%) (presumably organic 
material) and sea salt $(6.7 \%)$ were the main groups identified by using hierarchical cluster analysis applied to the X-ray intensities of all particles analyzed.

A key result found in this study is the link among residual cloud elements, airmass history and cloud phase. Two filters sampled under clear airmass conditions were dominated by low- $\mathrm{Z}$ and sea-salt elements, while those exposed during flights affected by mixed airmasses were dominated by mineral dust in the form of Fe-, Si-rich particles and aluminosilicates. The implications of the difference in cloud residual composition between these two types of airmass for cloud formation were quite pronounced when the cloud phase observed was compared for observation with similar thermodynamic conditions. In the marine-influenced clean airmass case the cloud remained liquid, while ice crystals were observed in the cases where mineral dust was the predominant aerosol residual. The former effect is believed to be due to the high organic aerosol loading in the marine air, which makes up a significant portion of the cloud condensation nuclei, facilitating droplet formation on one hand but inhibiting heterogeneous ice nucleation processes on the other hand. In the latter case, mineral dust coated with sulfates facilitated ice formation.

These results strongly suggest that organic aerosols can function as efficient CCN but its presence can delay or inhibit heterogeneous ice crystal formation, especially under atmospheric background conditions with low abundance of more suitable ice nuclei, like mineral dust.

The sources and the chemical components of organic aerosol (and their precursor acids) that act as $\mathrm{CCN}$ and alter hygroscopic behavior of atmospheric particles must be determined and mapped in order to assess their potential for cloud formation and modulation of cloud phase. This should have a considerable impact on the estimates of the cloud-mediated climate forcing due to changes in aerosol load and composition in the atmosphere.

Acknowledgements. Financial support for this work was given by the European Union under contract ENV4-CT97-0549. We thank the support from the Swedish Air Force (F4) in Östersund and the Swedish Meteorological service for the meteorological lee-wave forecasting during INTACC. The Royal Air Force aircrew of the MRFC-130 is also thanked for their assistance and cooperation in making successful atmospheric measurements during INTACC. Thanks also to M. Ahlbom from the Department of Geology and Geochemistry, Stockholm University for assistance on the operation of the SEM.

Edited by: Y. Rudich

\section{References}

Artaxo, P., Rabello, M. L. C., Maenhaut, W., and van Grieken, R.: Trace elements and individual particle analysis of atmo- spheric aerosols from the Antarctic peninsula, Tellus 44B, 318334, 1992.

Blanchard, D. C.: Sea-to-air transport of surface-active material, Science, 146, 396-397, 1964.

de Bock, L. A., Joos, P. E., Noone, K. J., Pockalny, R. A., and van Grieken, R. E.: Single Particle Analysis of aerosols, observed in the marine boundary layer during the Monterey Area Ship Tracks Experiment (MAST), with respect to cloud droplet formation, J. Atmos. Chem., 37, 299-329, 2000.

Cooper, W. and Vali, G.: The origin of ice in mountain cap clouds, J. Atmos. Sci., 38, 1244-1259, 1981.

Cziczo, D. J., DeMott, P. J., Brooks, S. D., Prenni, A. J., Thomson, D. S., Baumgardner, D., Wilson, J. C., Kreidenweis, S. M., and Murphy, D. M.: Observations of organic species and atmospheric ice formation, Geophys. Res. Lett., 31, L12116, doi:10.1029/2004GL019822, 2004.

Draxler, R. R. and Rolph, G. D.: HYSPLIT (HYbrid Single-Particle Lagrangian Integrated Trajectory) Model access via NOAA ARL READY Website (http://www.arl.noaa.gov/ready/hysplit4.html), NOAA Air Resources Laboratory, Silver Spring, MD, 2003.

Field, P. R., Cotton, R. J., Noone, K., Glantz, P., Kaye, P. H., Hirst E., Greenway, R. S., Jost, C., Gabriel, R., Reiner, T., Andreae, M., Saunders, C. P. S., Archer, A., Choularton, T., Smith, M., Brooks, B., Hoell, C., Bandy, B., Johnson, D., and Heymsfield, A.: Ice Nucleation in orographic wave clouds: Measurements made during INTACC, Q. J. R. Meteorol. Soc., 127, 1493-1512, 2001.

Fitzgerald, J. W.: Marine aerosols: A review, Atmos. Environ., 25A, 533-545, 1991.

Glantz P., Noone, K. J., and Osborne, S. R.: Comparisons of airborne CVI and FSSP measurements of cloud droplet number concentrations in marine stratocumulus clouds, Aerosol Sci. and Technol., 20(1), 133-142, 2003.

Georgii, H. W. and Kleinjung, E.: Relations between the chemical composition of atmospheric aerosol particles and the concentration of natural ice nuclei, J. Rech. Atmos., 3, 145-156, 1967.

Grosch, M. and Georgii, H. W.: Elemental composition of atmospheric aerosols and natural ice forming nuclei, J. Rech. Atmos., 10, 227-232, 1976.

Hallberg, A., Ogren, J. A., Noone, K. J., Heintzenberg, J., Berner, A., Solly, I., Kruisz, C., Reischl, G., Fuzzi, S., Facchini, M. C., Hansson, H. C., Wiedensohler, A., and Svenningsson, I. B.: Phase partitioning for different aerosol species in fog, Tellus 44B, 545-554, 1992.

Hallberg, A., Ogren, J. A., Noone, K. J., Okada, K., Heintzenberg, J., and Svenningsson, I. B.: The influence of aerosol particle composition on cloud droplet formation, J. Atmos. Chem., 19, 153-171, 1994.

Heintzenberg, J., Okada, K., and Ström, J.: On the composition of non-volatile material in upper tropospheric aerosols and cirrus, Atmos. Res., 41, 81-88, 1996.

Heymsfield, A. J. and Miloshevich, L. M.: Homogeneous ice nucleation and supercooled liquid water in orographic wave clouds, J. Atmos. Sci., 50(15), 2335-2353, 1993.

Hinds, W. C. Aerosol technology - Properties, behavior and measurement of airborne particles, 483, John Wiley \& Sons, New York, 1999.

Intergovernmental Panel on Climate Change (IPCC): Climate Change 2001: The Scientific Basis, edited by: Houghton, T., 
Ding, Y., Griggs, D. J., Noguer, M. P., van der Linden, J., et al., Cambridge University Press, New York, 2001.

Jensen, E. J., Toon, O. B., Tabazadeh, A., Sachse, G. W., Anderson, B. E., Chan, K. R., Twohy, C. W., Gandrud, B., Aulenbach, S. M., Heymsfield, A., Hallett, J., and Gary, B.: Ice nucleation processes in upper tropospheric wave-clouds observed during SUCCESS, Geophys. Res. Lett., 25, 1363-1366, 1998.

Krejci, R., Ström, J., de Reus, M., and Sahle, W.: Single particle analysis of the accumulation mode aerosol over the northeast Amazonian tropical rain forest, Surinam, South America, Atmos. Chem. Phys. Discuss., 4, 533-568, 2004.

Levin, Z., Ganor, E., and Gladstein, V.: The effects of desert particles coated with sulfate on rain formation in the eastern mediterranean, J. Appl. Meteorol., 35, 1511-1523, 1996.

Liu, X., van Espen, P., Adams, F., Cafmeyer, J., and Maenhaut, W.: Biomass burning in southern Africa: individual particle characterization of atmospheric aerosols and savanna fire samples, J. Atmos. Chem., 36, 135-155, 2000.

Mamane, Y. and Noll, K. E.: Characterization of large particles at a rural site in the eastern United States: Mass distribution and individual particle analysis, Atmos. Environ., 19, 611-622, 1985.

Mamane, Y., Ganor, E., and Donagi, A. E.: Aerosol composition of urban and desert origin in the Eastern Mediterranean - I. Individual particle analysis, Water Air Soil Pollut., 14, 29-43, 1980.

Matsumoto, K., Tanaka, H., Nagao, I., and Ishizaka, Y.: Contribution of particulate sulfate and organic carbon to cloud condensation nuclei in the marine atmosphere, Geophys. Res. Lett., 24, 655-658, 1997.

Murphy, D. M., Cziczo, D. J., Hudson, P. K., Thomson, D. S., Wilson, J. C., Kojima, T., and Buseck, P. R.: Particle generation and resuspension in aircraft inlets when flying in clouds, Aerosol Sci. and Technol., 38, 401-409, 2004.

Noone, K. J., Ogren, J. A., Heintzenberg, J., Charlson, R. J., and Covert, D. S.: Design and calibration of a counterflow virtual impactor for sampling of atmospheric fog and cloud droplets, Aerosol Sci. and Technol., 8, 235-244, 1988.

Noone, K. B., Noone, K. J., Heintzenberg, J., Ström, J., and Ogren, J. A: In situ observations of cirrus cloud microphysical properties using the counterflow virtual impactor, J. Atmos. Oceanic Technol., 10, 294-303, 1993.

Noone, K. J., Öström, E., Ferek, R. J., Garrett, T., Hobbs, P. V., Johnson, D. W., Taylor, J. P., Russell, L. M., Flagan, R. C., Seinfeld, J. H., O'Dowd, C. D., Smith, M. H., Durkee, P. A., Nielsen, K., Hudson, J. G., Pockalny, R. A., De Bock, L., van Grieken, R. E., Gasparovic, R. F., and Brooks, I.: A case study of ships forming and not forming tracks in moderately polluted clouds, $\mathrm{J}$. Atmos. Sci., 57(16), 2729-2747, 2000.
Novakov, T. and Penner, J. E.: Large contribution of organic aerosols to cloud-condensation-nuclei concentrations, Nature, 365, 823-826, 1993.

Novakov, T., Corriga, C. E., Penner, J. E., Chuang, C. C., Rosario, O., and Mayol Bracero, O. L.: Organic aerosols in the Caribbean trade winds: a natural source?, J. Geophys. Res., 102(D17), $21307-21313,1997$.

Petzold, A., Ström, J., Ohlsson, S., and Schröder, F. P.: Elemental composition and morphology of ice crystal residues in cirrus clouds and contrails, Atmos. Res., 49, 21-34, 1998.

Russell, L. M., Noone, K. J., Ferek, R. J., Pockalny, R. A., Flagan, R. C., and Seinfeld, J. H.: Combustion organic aerosol as cloud condensation nuclei in ship tracks, J. Atmos. Sci., 57(16), 25912606, 2000.

Reid, E. A., Reid, J. S., Meier, M. M., Dunlap, M. R., Cliff, S. S., Broumas, A., Perry, K., and Maring, H.: Characterization of African dust transported to Puerto Rico by individual particle size segregated bulk analysis, J. Geophys. Res., 108(D19), 8591, doi:10.1029/2002JD002935, 2003.

Rivera-Carpio, C. A., Corrigan, C. E., Novakov, T., Rogers, C. F., and Chow, J. C.: Derivation of contributions of sulfate and carbonaceous aerosols to cloud condensation nuclei from mass size distributions, J. Geophys. Res., 101(D14), 19483-19493, 1996.

Seifert, M., Ström, J., Krejci, R., Minikin, A., Petzold, A., Gayet, J.F., Schumann, U., and Ovarlez, J.: In situ observations of aerosol particles remaining from evaporated cirrus crystals: Comparing clean and polluted airmasses, Atmos. Chem. Phys., 3, 10371049, 2003.

Schaap, M., Muller, K., and ten Brink, H. M.: Constructing the European aerosol nitrate concentration field from quality analysed data, Atmos. Environ, 36, 8, 1323-1335, 2002.

Sobranska, S., Pauwels, B., Maenhault, W., and Adams, F.: Single particle characterization and sources of tropospheric aerosols in the Negrev desert (Israel), J. Phys. IV France, 12, doi:10.1051/jp4:20020458, 2002.

Vali, G.: Nucleation terminology, Bull. Amer. Meteor. Soc., 66, 1426, 1985.

Ward, J. H.: Hierarchical grouping to optimize an objective function, J. Amer. Assoc., 58, 236-244, 1963.

Xhoffer, C., Bernard, P., and van Grieken, R.: Chemical characterization and source apportionment of individual aerosol particles over the North Sea and the English Channel using multivariate techniques, Environ. Sci. Technol., 25, 1470-1478, 1991.

Yeh, Y. and Feeeny, R. E.: Antifreeze proteins: structures and mechanisms of function, Chem. Rev., 96, 601-617, 1996. 